DOI: 10.37863/umzh.v73i10.6926

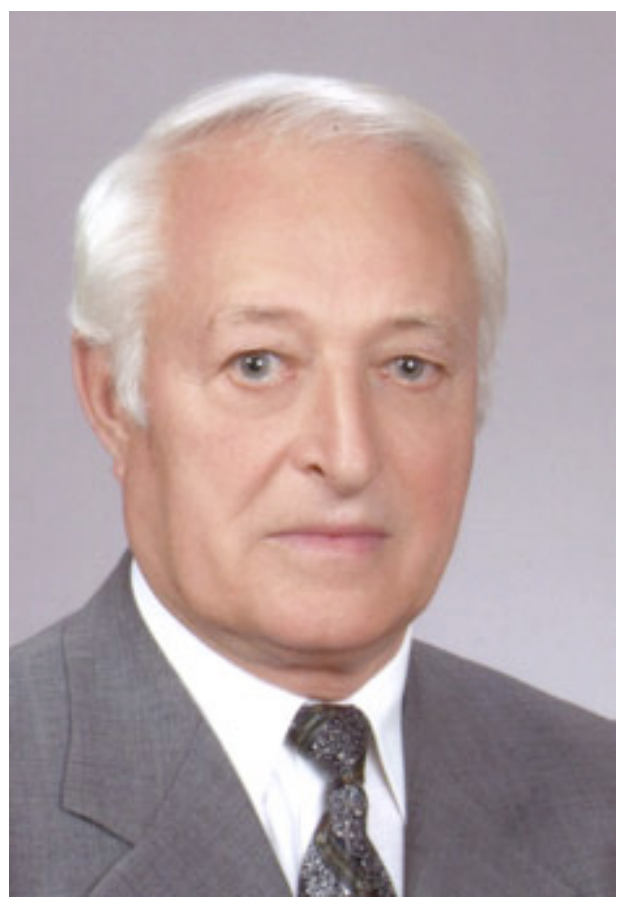

\title{
ІВАН ОЛЕКСАНДРОВИЧ ЛУКОВСЬКИЙ (до 85-річчя від дня народження)
}

Рік тому, 24 вересня 2020 року, виповнилося 85 років видатному українському ма тематику, академіку НАН України Івану Олександровичу Луковському.

Академік Луковський є засновником кількох наукових шкіл у галузях аналітичної механіки, математичноої фізики, диференціальних рівнянь, обчислювальної математики та теорії керувань, які так чи інакше пов'язані з дослідженнями математичних проблем механіки. Іван Олександрович заснував математичну базу для аналітичних досліджень та побудови чисельноаналітичних розв'язків нелінійних задач з вільною межею, які виникають в динаміці твердих та деформівних тіл, що несуть рідину, розвинув варіаційний формалізм Бейтмена - Люка для крайових задач гідродинамічного типу, запропонував наближено-аналітичні методи розв'язування базових гідродинамічних крайових задач механіки обмеженого об'єму рідини, створив математичну теорію спектральних крайових задач з параметром у крайових умовах тощо. $\mathrm{У}$ скарбницю світової науки увійшли такі „іменні” поняття, як модальна система Майлза Луковського, формули Луковського для гідродинамічних сил та моментів, а також метод неконформних трансформацій Луковського розв'язування задачі про коливання рідини в баках складної геометрії.

Наукові досягнення І. О. Луковського відзначено Державною премією УРСР у галузі науки і техніки, преміями НАН України ім. М. К. Янгеля, М. М. Крилова, М. М. Боголюбова, ( ) РЕДКОЛЕГІЯ „УКРАЇНСЬКОГО МАТЕМАТИЧНОГО ЖУРНАЛУ”, 2021 
М. О. Лаврентьєва та М. В. Остроградського. В ін нагороджений медаллю „За трудову доблесть”, Почесною Грамотою Президії Верховної Ради УРСР, а також орденом „За заслуги” III ступеня, має звання Заслуженого діяча науки і техніки України.

Наукова громадськість, учні, друзі й співробітники та редакційна колегія ще раз сердечно вітають Івана Олександровича 3 ювілеєм і бажають йому міцного здоров'я, довгих щасливих років життя і нових творчих звершень.

Редколегія , Українського математичного журналу” 